\title{
Corrigendum: Using a Crop Modeling Framework for Precision Cost-Benefit Analysis of Variable Seeding and Nitrogen Application Rates
}

\author{
Gabriel McNunn, Emily Heaton, Sotirios Archontoulis, Mark Licht and Andy VanLoocke* \\ Department of Agronomy, lowa State University, Ames, IA, United States
}

Keywords: economic optimum nitrogen, economic optimum seeding, nitrate leaching, APSIM, model framework

OPEN ACCESS

Edited and reviewed by:

Stacy Michelle Philpott, University of California, Santa Cruz,

United States

*Correspondence:

Andy VanLoocke

andyvan/@iastate.edu

Specialty section:

This article was submitted to Agroecology and Ecosystem Services,

a section of the journal

Frontiers in Sustainable Food Systems

Received: 19 August 2020 Accepted: 10 September 2020

Published: 30 October 2020

Citation:

McNunn G, Heaton E, Archontoulis $S$,

Licht $M$ and VanLoocke A (2020)

Corrigendum: Using a Crop Modeling Framework for Precision Cost-Benefit

Analysis of Variable Seeding and

Nitrogen Application Rates.

Front. Sustain. Food Syst. 4:596523.

doi: $10.3389 /$ fsufs. 2020.596523

\section{A Corrigendum on}

Using a Crop Modeling Framework for Precision Cost-Benefit Analysis of Variable Seeding and Nitrogen Application Rates

by McNunn, G., Heaton, E., Archontoulis, S., Licht, M., and VanLoocke, A. (2019). Front. Sustain. Food Syst. 3:108. doi: 10.3389/fsufs.2019.00108

In the original article, there was an error. The authors would like to further expand on the specific novel innovations developed from this work compared to similar modeling studies that were developed independently over the same time period.

A correction has been made to Introduction, Paragraph 5:

"Similar frameworks linking public soils and weather data with environmental models (including APSIM) have been implemented (Zhang et al., 2010; Brandes et al., 2018; Jin et al., 2019) and found support for individual precision management options in terms of economic and environmental factors. The novel component of our analysis is that we developed a system for guiding subfield management decisions based on multiple economic cost drivers (seed and $\mathrm{N}$ fertilizer inputs) that directly influence potential yield (Al-Kaisi and Yin, 2003) and interact with subsequent environmental performance and profitability."

A correction has been made to Discussion, Paragraph 2:

"Similar geographical focus was given in Jin et al. (2019), which used an APSIM framework to estimate regional economic optimum nitrogen fertilizer rates based on subfield management zone simulations across many Midwest fields.”

The authors apologize for this error and state that this does not change the scientific conclusions of the article in any way. The original article has been updated. 


\section{REFERENCES}

Al-Kaisi, M., and Yin, X. (2003). Effects of nitrogen rate, irrigation rate, and plant population on corn yield and water use efficiency. Agron. J. 95, 1475-1482. doi: 10.2134/AGRONJ2003.1475

Brandes, E., McNunn, G. S., Schulte, L. A., Muth, D. J., VanLoocke, A., and Heaton, E. A. (2018). Targeted subfield switchgrass integration could improve the farm economy, water quality, and bioenergy feedstock production. GCB Bioenergy 10, 199-212. doi: 10.1111/gcbb.12481

Jin, Z., Archontoulis, S. V., and Lobel, D. B. (2019). How much will precision nitrogen management pay off? An evaluation of simulating thousands of corn fields over the US Corn-Belt. Field Crops Res. 240, 12-22. doi: $10.1016 /$ j.fcr.2019.04.013
Zhang, X., Izaurralde, R. C., Manowitz, D., West, T. O., Post, W. M., Thomson, A. M., et al. (2010). An integrative modeling framework to evaluate the productivity and sustainability of biofuel crop production systems. Global Change Biol. 2, 258-277. doi: 10.1111/j.1757-1707.2010. 01046.x

Copyright (C) 2020 McNunn, Heaton, Archontoulis, Licht and VanLoocke. This is an open-access article distributed under the terms of the Creative Commons Attribution License (CC BY). The use, distribution or reproduction in other forums is permitted, provided the original author(s) and the copyright owner(s) are credited and that the original publication in this journal is cited, in accordance with accepted academic practice. No use, distribution or reproduction is permitted which does not comply with these terms. 